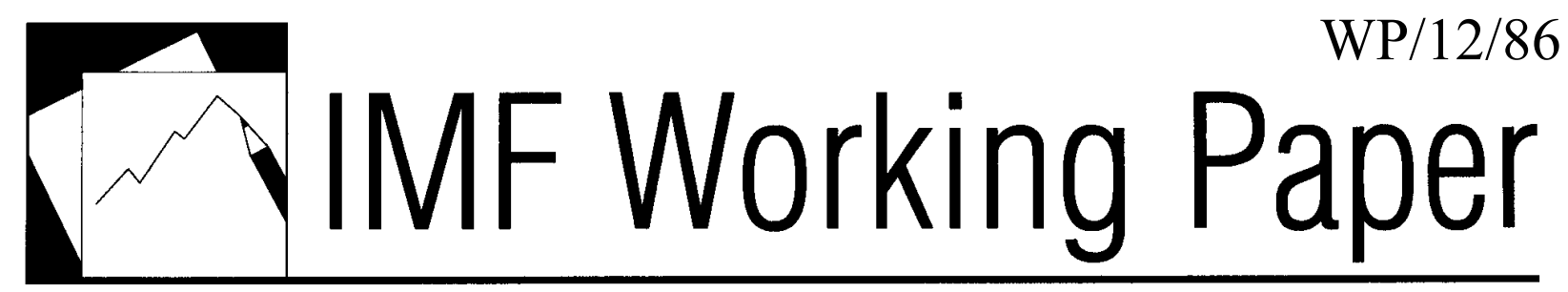

\title{
Global Food Price Inflation and Policy Responses in Central Asia
}

Ali Al-Eyd, David Amaglobeli, Bahrom Shukurov, and Mariusz Sumlinski 


\title{
IMF Working Paper
}

Middle East and Central Asia Department

\section{Global Food Price Inflation and Policy Responses in Central Asia}

Prepared by Ali Al-Eyd, David Amaglobeli, Bahrom Shukurov, and Mariusz Sumlinski*

Authorized for distribution by Ana Lucía Coronel

March 2012

\section{This Working Paper should not be reported as representing the views of the IMF.} The views expressed in this Working Paper are those of the author(s) and do not necessarily represent those of the IMF or IMF policy. Working Papers describe research in progress by the author(s) and are published to elicit comments and to further debate.

\begin{abstract}
This paper examines the implications of elevated global food prices for inflation in select Central Asian economies - Kazakhstan, the Kyrgyz Republic, Tajikistan, and Uzbekistan. The findings suggest that global food inflation has significant short-run effects that build over time. Inflation outcomes simulated under alternative global wheat price assumptions underscore these vulnerabilities, and suggest that sustained administrative measures are unlikely to prove effective. In line with structural economic features, the interest rate channel of monetary policy is found to be limited, arguing for a broad policy strategy to control more expansive inflationary pressures. Looking ahead, measures to enhance supply responses, deepen domestic financial markets, develop adequate social safety nets, and increase central bank independence are warranted.

JEL Classification Numbers: E31, E37, E58

Keywords: Central Asia, inflation, food price shocks, policy responses, monetary policy

Author's E-Mail Addresses: aaleyd@,imf.org, damaglobeli@imf.org, bshukurov@imf.org, msumlinski@,imf.org

\footnotetext{
* The authors would like to thank Ana Lucía Coronel for valuable comments. The paper also benefitted from useful comments from David Owen, Paul Cashin, Todd Schneider, Nadeem Ilahi, Dmitriy Rozhkov, and Galina Kostina. The authors thank Mehmet Cangul for excellent research assistance.
} 
Abstract 1

I. Introduction 4

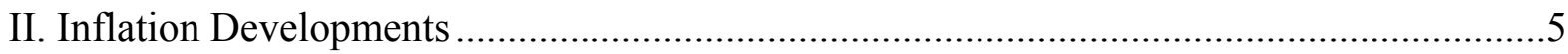

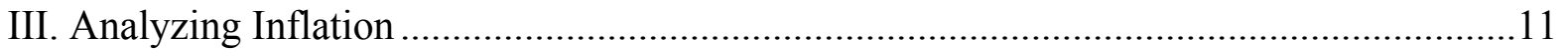

IV. Global Food Shocks and CA-4 Policy Measures ....................................................... 15

V. Policy Considerations and Conclusions .................................................................. 16

Tables

Table B1.1. Major food staples in the CA-4 ...................................................................... 7

Table B1.2. Major food staples in the CA-4 - weights in CPI and poverty measures .............7

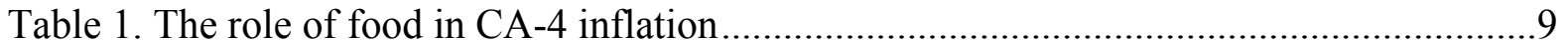

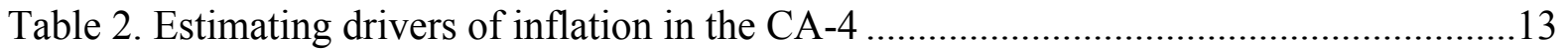

Table B3.1. Alternative inflation forecasts for 2012 ..................................................... 15

Table B4.1: Measures of central bank independence in the CA-4 ......................................16

Figures

Figure 1. Global commodity prices and inflation developments in the CA-4 ......................6

Figure 2. CA-4 Macroeconomic and financial indicators..............................................8

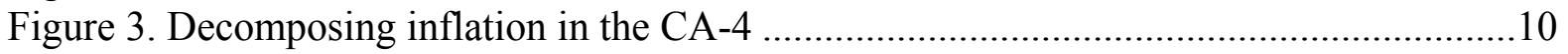

Figure 4. A comparison of the inflation impact between the 2007 and 2010 shocks .............11

Figure B3.1. Global wheat price scenarios and CA-4 bread inflation ...................................14

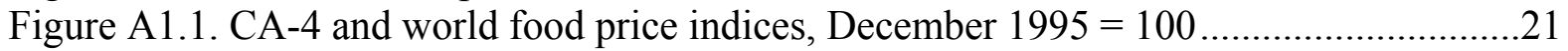

\section{Boxes}

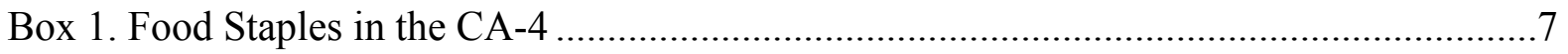

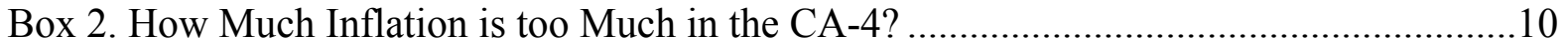

Box 3. Simulating a Sustained Global Wheat Price Shock ...................................................14

Box 4. Central Bank Independence in the CA-4...........................................................16

Appendices

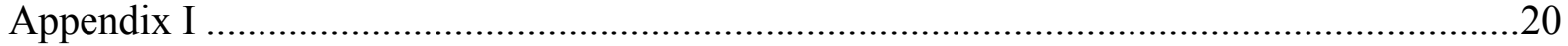

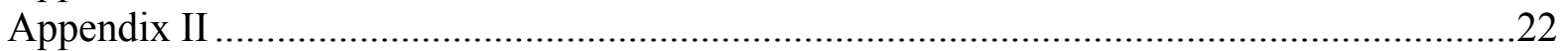

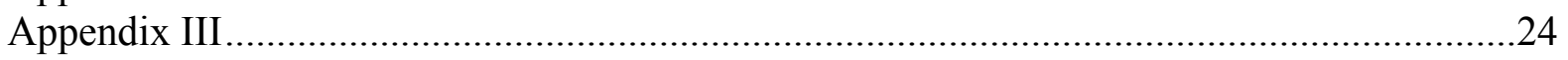

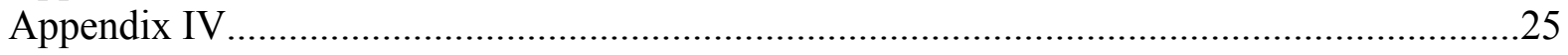

Appendix Tables

Table A1.1. Major food staples in the CA-4-Demand and supply...................................20

Table A1.2. Major food staples in the CA-4-Production and exports...............................20

Table A2.1. Public policy responses to food price increases $2007-08$.................................22 


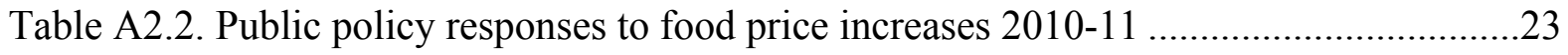

Table A3.1. Estimating global wheat impacts on bread price inflation.................................24

Table A4.1. Questionnaire on transparency of central bank operations ...............................25

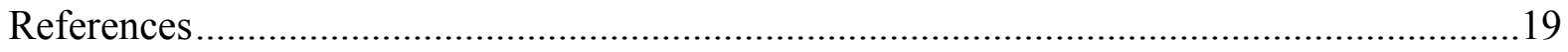




\section{INTRODUCTION}

Recent marked rises in global food and energy prices have revived concerns about the emergence of sustained inflationary pressures and the appropriate policy responses in many economies. These concerns are well justified in the Central Asian economies of Kazakhstan, the Kyrgyz Republic, Tajikistan, and Uzbekistan (CA-4), where headline inflation has increased, largely owing to rising food prices. ${ }^{1}$ Global food-driven rises in inflation have been larger in CA-4 than in other regions of the world, and have also been slower to decline. In addition, core inflation has increased in the Kyrgyz Republic, Tajikistan, and Uzbekistan even though there are no clear signs of overheating.

The authorities reacted to these shocks by controlling food prices, mostly through administrative measures and export restrictions, and in some cases limited monetary tightening. However, fighting more broad-based price pressures may prove challenging should elevated global commodity prices contribute to pronounced second-round inflationary effects. ${ }^{2}$ In this case, the authorities would need to use macroeconomic policies to control inflation, intensifying the difficult balance between supporting economic recoveries and achieving price objectives. This task would be further complicated in the post-crisis environment of impaired bank balance sheets, depreciated exchange rates, lower or stagnant incomes, and elevated social costs of inflation.

Against this background, this paper analyzes the key drivers of inflation in the CA-4. Estimations using a panel data framework find that global food price inflation has a strong and significant short-run effect on headline inflation. In addition, reflecting the structural features of the CA-4, the transmission of monetary policy through interest rate channels is limited, impacting with a moderate lag. Using country-specific models, inflation outcomes are simulated under alternative global wheat price assumptions to capture the importance of bread and cereals products in the consumption baskets of the CA-4. The combined analyses suggest that these economies are vulnerable to a sustained shock to global food prices, particularly the net food importers: the Kyrgyz Republic and Tajikistan.

The findings presented here underscore the need for a broad policy strategy to control global food price-driven inflation in the CA-4. Anti-inflationary policies should be based on forward-looking assessments by central banks, effective communication of their policy decisions, and possibly a reconsideration of implicit exchange rate targets as part of a wider policy response. Policymakers should monitor both core and headline inflation, and should identify and communicate the factors that determine inflation. In addition, fiscal policy should be supportive of price stability, and anti-inflationary administrative measures should be phased out in favor of well targeted social assistance to the most vulnerable groups.

\footnotetext{
${ }^{1}$ Turkmenistan is excluded from the analysis because of limited data availability.

${ }^{2}$ See the April and September 2011 World Economic Outlooks. In particular, the stock-to-use ratios are expected to remain below long-term averages, limiting the capacity of some major food commodity markets to absorb further supply shocks. This suggests that food prices will remain subject to upside risks over the medium term.
} 
Further ahead, structural reforms are needed in the CA-4 to strengthen central bank independence and the monetary toolkit, and to promote domestic financial market development. Enhancements of labor market flexibility, productivity and competitiveness should complement these efforts.

\section{INFLATION DEVELOPMENTS}

Prior to the surge of global wheat prices in mid 2010, inflationary pressures in the CA-4 were relatively subdued. At the beginning of 2010 , measures of headline inflation in all countries were close to levels in mid-2007, before the previous commodity price shock emerged. However, as global wheat prices increased in the second half of 2010, inflation in the Kyrgyz Republic and, to a lesser extent, Tajikistan accelerated markedly, and prices in Kazakhstan and Uzbekistan also showed upward pressure. In addition to the increase of wheat prices, the prices of other key global commodities (corn, sugar, and soybeans) as well as oil and energy had risen, adversely affecting not only the price of staple foods but also the terms of trade in the oil importing countries (Box 1). The inflation spike observed in 2010 in the CA-4 was larger than in other parts of the world and the decline in inflation has been slower as well. 
Figure 1. Global commodity prices and inflation developments in the CA-4
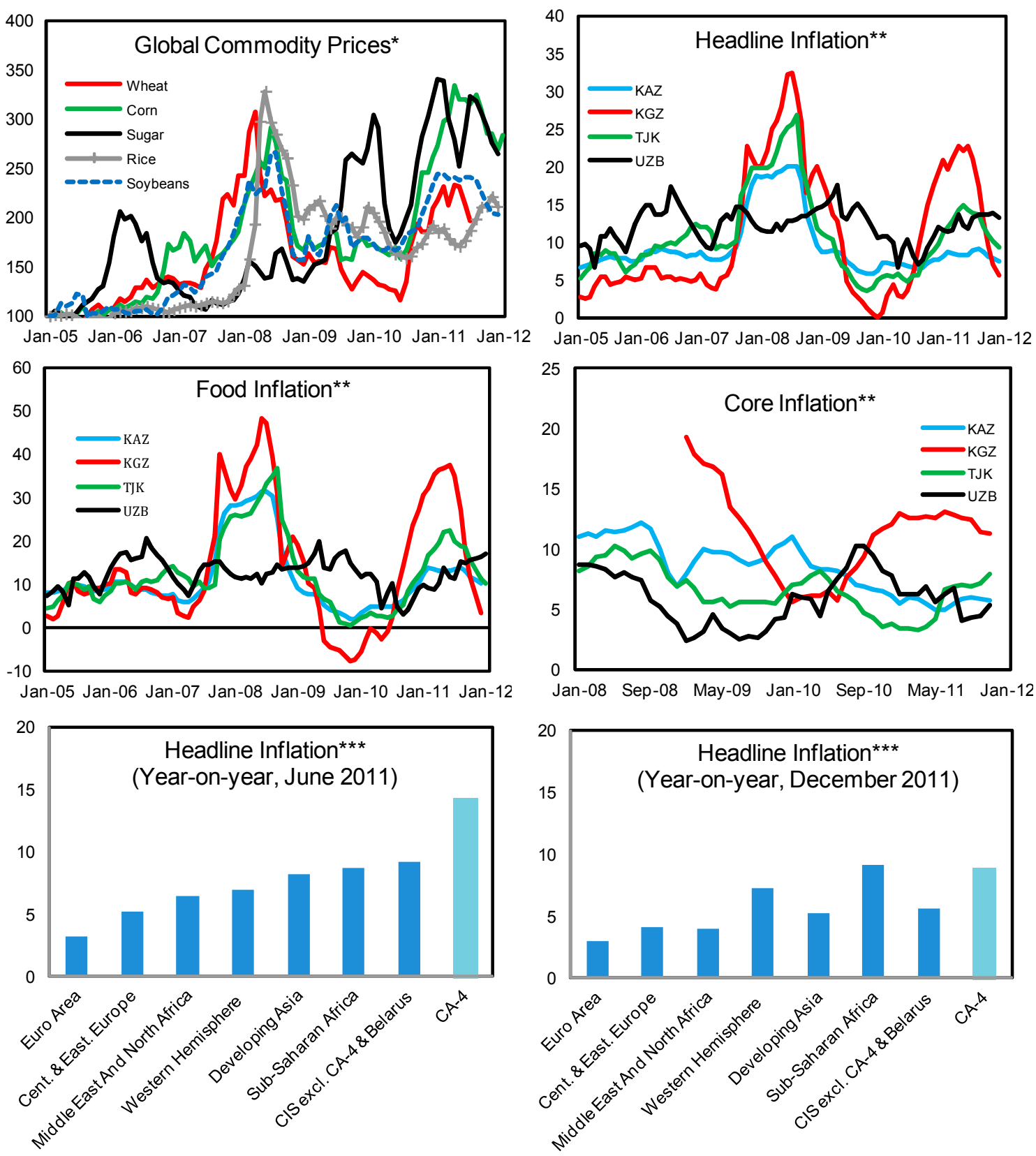

Sources: Country authorities, and staff estimates.

* January $2005=100$

** Percent, year-on-year.

*** Belarus was excluded from the sam ple because the recent inflation spike was unrelated to global food prices. 


\section{Box 1. Food Staples in the CA-4}

Staples commonly consumed across the CA-4 account for the majority of CPI food baskets (Table B1.1). The weights of these staples range from 50 percent of the CPI food basket weight in the Kyrgyz Republic to 70 percent in the others. The Kyrgyz Republic, Tajikistan, and Uzbekistan have nearly identical staple food baskets, while Kazakhstan shares six of staples with the others.

All staples are produced domestically, but domestic supplies of some-sugar, vegetable oil, flour, and potatoes - are supplemented with imports (Appendix I, Table A1.1). The Kyrgyz Republic and Tajikistan depend heavily on imports of flour, potatoes, and vegetable oil. Hence, the domestic prices of these products are heavily affected by global price movements. However, apart from these few exceptions, price trends of common staples are largely domestically determined.

Some common staples are exported by the CA-4, most notably carrots and onions, but the region is generally ranked well below other exporters of respective staples (Appendix I, Table A1.2). There are a few exceptions, with Kazakhstan ranking number one and 14 among flour and rice exporters. While exports from the region generally account for a fraction of world supply, and consequently have little effect on world prices, they constitute a noticeable portion of domestic production. Owing to this, the CA-4 can redirect exports to domestic markets if necessary, or benefit from the rising world prices.

Domestic price trends of staple items have broadly mirrored global trends (Appendix I). However, while domestic prices rise in tandem with world prices they do not tend to decline to the same extent that world prices do. This may be owing to local market inefficiencies, domestic monopolies, and limited global trade integration.

Table B1.1. Major food staples in the CA-4

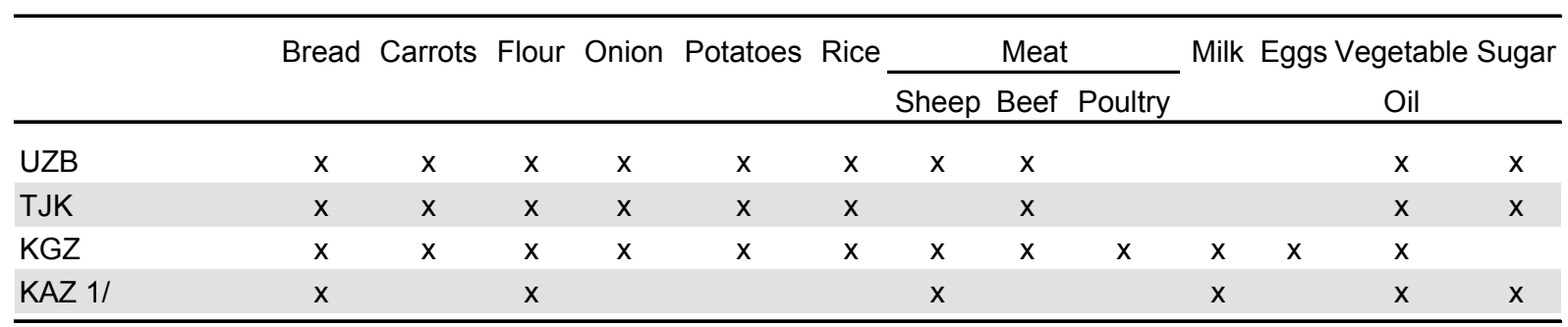

$1 /$ Vegetable oil includes butter; milk=dairy.

Table B1.2. Major food staples in the CA-4-weights in CPI and poverty measures

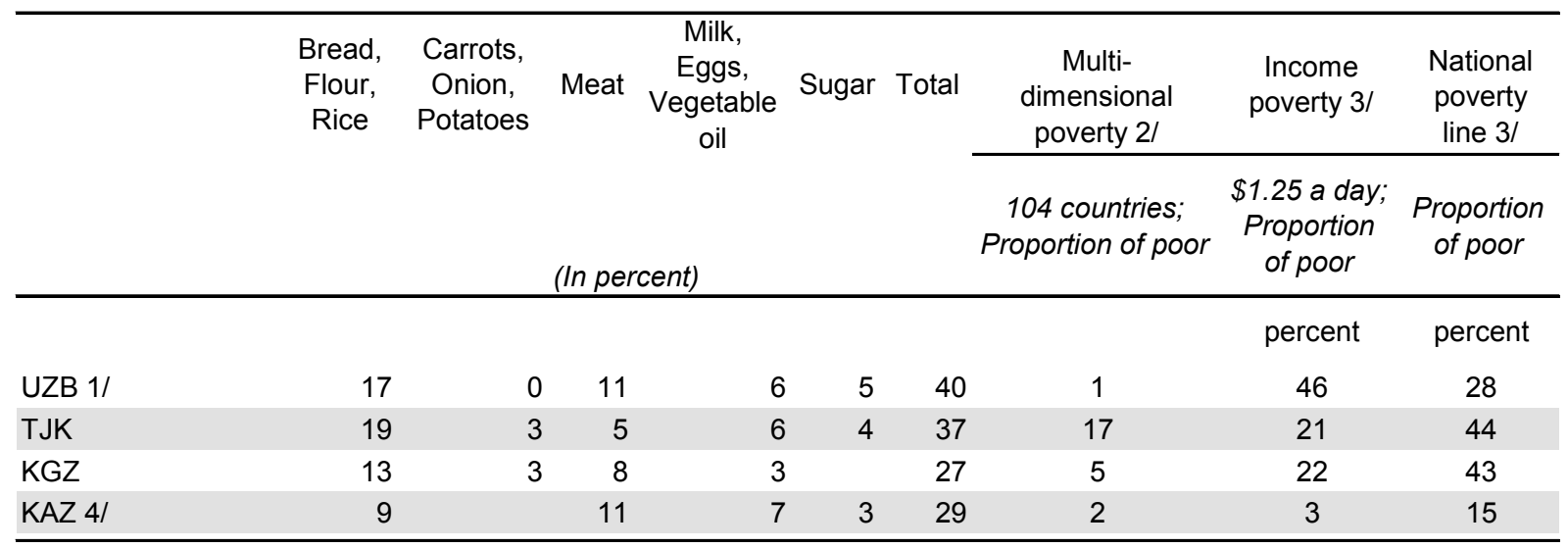

$1 /$ Weights for carrots, potatoes, and onion change monthly; meat includes meat, poultry, and fish; oil includes oil, butter, and fat; sugar includes sugar and tea.

2/ Oxford Poverty and Human Development Initiative Working Paper 38, July 2010, Table 1.1.

3/ Authorities' estimates. The latest available year (2003-08), 2009 World Development Indicators, World Bank.

4/ Oil includes oil and butter; sugar includes confectionary. 
The macroeconomic conditions in 2010 and the uncertain outlook for global commodity prices increased uncertainty regarding future inflation developments in the CA-4. Economic recoveries had begun to firm up, aided by improving global conditions and accommodative monetary and fiscal policies throughout the crisis. While key policy rates had been raised in some countries, real interest rates were negative or close to zero in all (Figure 2). Real credit and income growth was generally weak, but strong base money expansion underscored the potential for future inflationary pressures. In addition, significant crisis-related nominal devaluations, which left the values of currencies 20-30 percent below their pre-crisis levels (except in Uzbekistan), shook the confidence in national currencies and potentially weakened their role as anchors for inflation expectations. ${ }^{3}$

Figure 2. CA-4 Macroeconomic and financial indicators
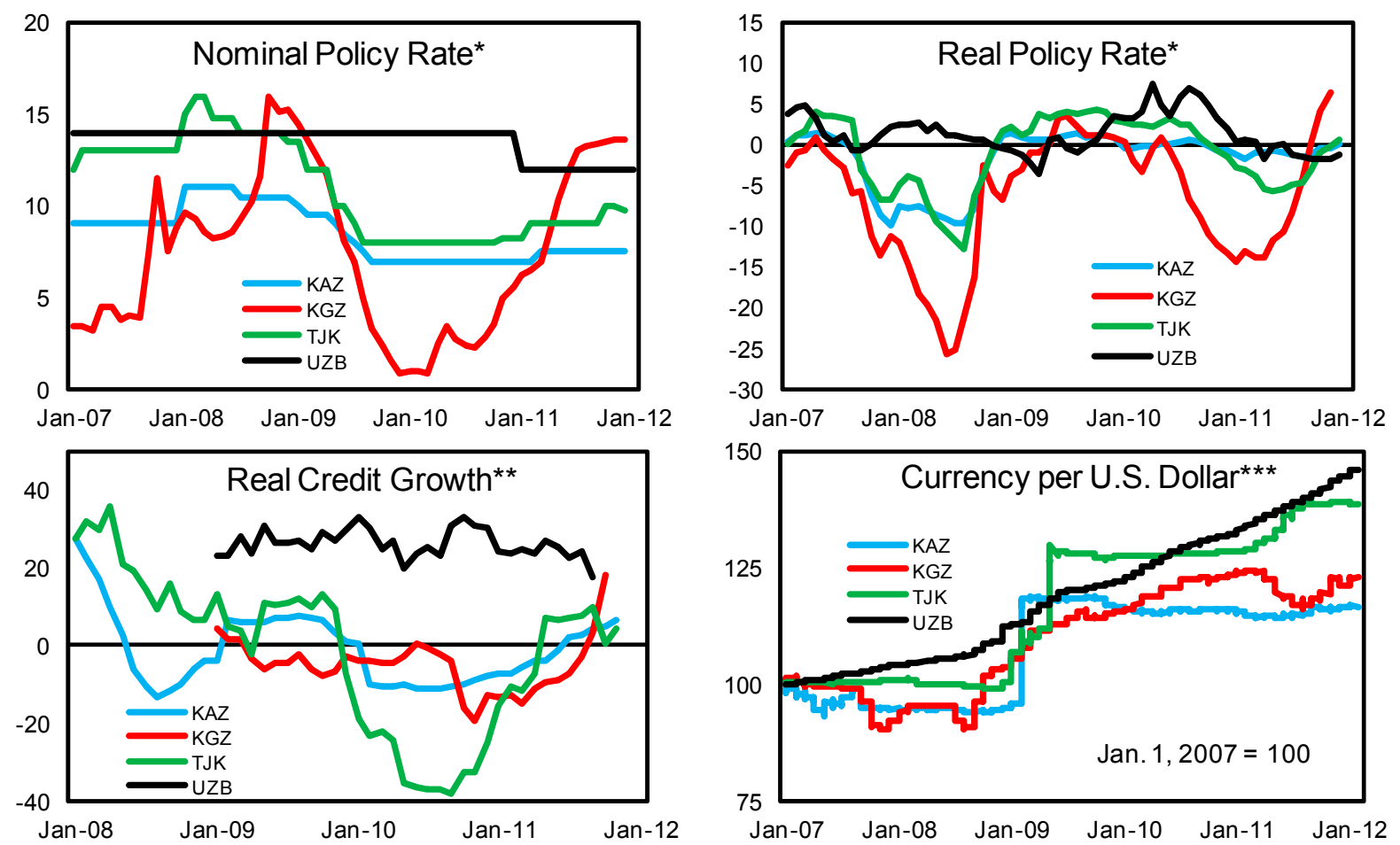

Sources: Country auth orities, staff estimates, and Bloomberg.

* Percent. The real policy rate is derived using current dated in flation.

${ }^{* *}$ Annual percent.

*** Local currency perU.S. dollar, index January 1, $2007=100$.

\footnotetext{
${ }^{3}$ Uzbekistan did not experience a crisis-induced devaluation, but maintains a crawling exchange rate arrangement that targets 8 percent nominal depreciation per year.
} 
As in other low and middle income countries, food and energy account for a large share of the CPI baskets in the CA-4. In the Kyrgyz Republic, Tajikistan, and Uzbekistan the share of food is about 58 percent, while in Kazakhstan, which is relatively richer than its neighbors, the share of food is lower at 39 percent. ${ }^{4}$ In addition, the correlation between poverty and a high share of income outlays on food provides a strong link between food price movements, headline inflation, and inflation expectations. ${ }^{5}$

\begin{tabular}{|c|c|c|c|c|}
\hline & KAZ & KGZ & TJK & UZB \\
\hline Food share in CPI $1 /$ & 38.8 & 57.1 & 57.6 & 58.1 \\
\hline Of which: Bread Products 2/ & 8.5 & 19.5 & 21.5 & 16.9 \\
\hline Energy share in $\mathrm{CPI}$ & 11.0 & $6.9^{*}$ & 4.7 & $5^{* *}$ \\
\hline \multicolumn{5}{|c|}{ Correlation between Global Food Prices and: } \\
\hline Headline Inflation 3/ & 0.81 & 0.80 & 0.82 & 0.76 \\
\hline Food Inflation & 0.86 & 0.87 & 0.86 & 0.80 \\
\hline Food share in imports $4 /$ & 5.6 & 13.9 & 16.1 & 7.3 \\
\hline Net food importer & No & Yes & Yes & No \\
\hline
\end{tabular}

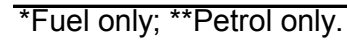

1/ As of 2010. For KGZ and TJK this includes: food, beverages, and tobacco. For KAZ this includes: food and nonalcoholic beverages. For UZB this includes: food and beverages.

2/ Varies by country, but includes items such as bread, grain, and cereals.

3/ Based on prices between January 2004 and April 2011.

4/ As of end 2010 except TJK, which reflects end 2009 data.

Sources: Country authorities' data, staff estimates, UN Comtrade, and Food \& Agricultural Organization of the United Nations (FAO).

Food price inflation has been a major contributor to the recent surges in headline inflation in the CA-4. A simple decomposition of inflation covering the recent global commodity shocks shows the high relative contributions of food and wheat-related (bread) subcomponents (Figure 2). Domestic food prices appear to adjust quickly and in line with changes in global food prices. Although the contributions of non-food and services inflation remain relatively constant over time, mainly because of their small weight in the CPI baskets, they are susceptible to second round effects. The combination of factors suggests that high global food prices quickly pass-through to headline inflation and also have some effects on core inflation in these countries.

\footnotetext{
${ }^{4}$ This food share of CPI for Kazakhstan includes food, beverages and tobacco.

${ }^{5}$ The income poverty rate is the percentage of the population living on less than $\$ 2.00$ a day at 2005 international prices for the latest year available; World Bank http://data.worldbank.org/indicator/SI.POV.2DAY/countries/UZ?display=graph
} 
Figure 3. Decomposing inflation in the CA-4

(In percentage points)
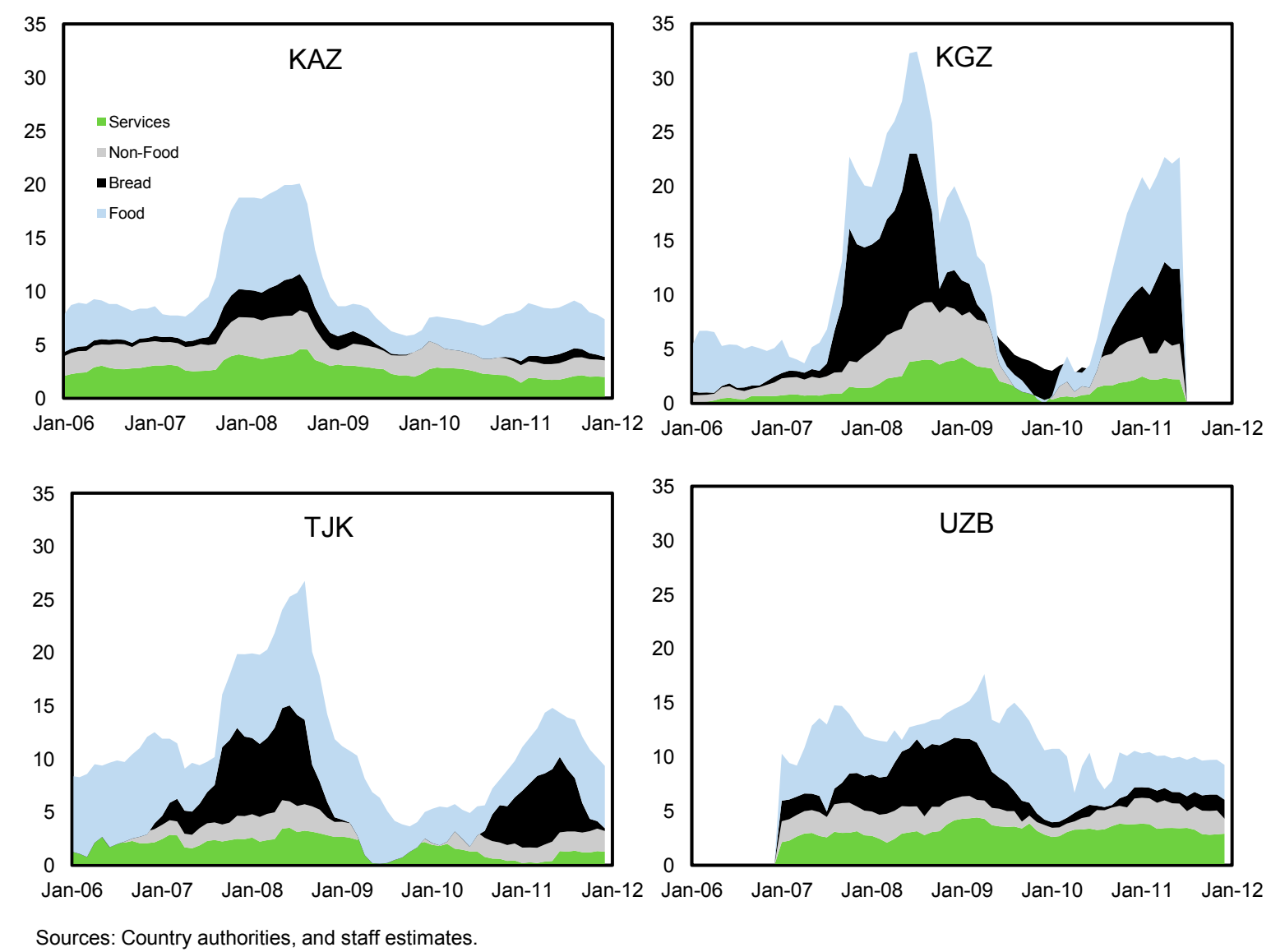

\section{Box 2. How Much Inflation is too Much in the CA-4?}

While for most countries of the world hyperinflations are the long forgotten past, for the CA-4 this is part of relatively recent history. Kazakhstan, the Kyrgyz Republic, Tajikistan, and Uzbekistan experienced hyperinflation, with annual inflation rates exceeding 1000 percent at times during 1992-94. Disciplined macroeconomic policies have since contributed to rapid and sustained disinflations, but the episodes of the early 1990s remain vivid for policymakers and those who lost their life savings.

Inflationary expectations affect macroeconomic policy management and inflation outcomes. Given high poverty rates, the adverse impact of inflation is felt by most of the population. Moreover, high inflation generates inefficiencies that reduce long-term economic growth. Therefore, achieving low and non-accelerating (i.e. "benign") inflation should be an important priority on the authorities' policy agenda.

An inflation level below which inflation is "benign" is likely to vary by country. Indeed, cross-country empirical studies claim that the relationship between inflation and growth is nonlinear in nature. Up to a certain "threshold level" inflation does not significantly undermine growth. While the threshold level of inflation in developing countries is estimated to be 7-11 percent (Khan and Senhadji, 2000), many of these countries have chosen to set inflation objectives on the lower side of this range and closer to industrial countries' goals. 
Although the most recent increases in headline and food inflation in the CA-4 have been considerable, they remain below those seen during the previous shock. A comparison of headline and food inflation during the first 12 months of each episode shows that the overall impact has been less pronounced during the 2010-11 shock than during 2007-08 (Figure 3). While the magnitude of the current food shock is somewhat smaller than previously, it is likely that the use of more extensive administrative measures in some countries - notably in Kazakhstan and Tajikistan - mitigated the initial impact of the shock during the first six months, limiting the overall effect in the first year. ${ }^{6}$ In Uzbekistan, where administrative responses have been more limited, the overall food and headline inflation impact has been similar over the two episodes. The divergence in price effects between the shock episodes, therefore, likely reflects a combination of factors, including variations in the implementation of administrative measures, as well as the weights given to bread and wheat products, which more directly capture the nature of the current wheat-driven shock (Table 1). ${ }^{7}$

Figure 4. A comparison of the inflation impact between the 2007 and 2010 shocks
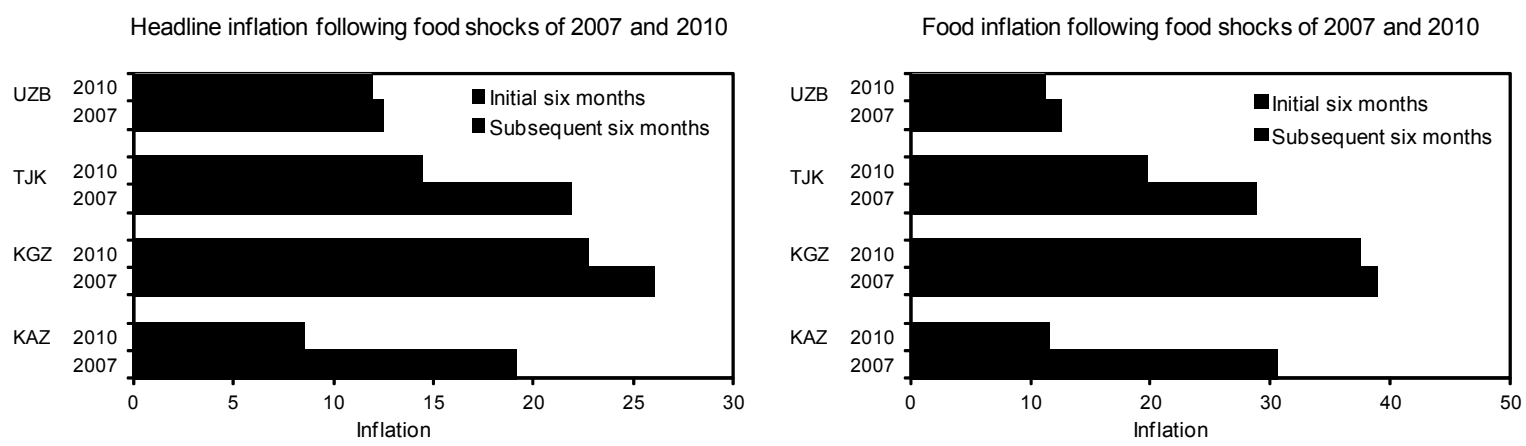

III. ANALYZING INFLATiON

Elevated global food prices add to the uncertainty regarding the inflation outlook in the CA-4. While the food price inflation of 2007-08 illustrates the vulnerabilities of each country to surging global food prices, the current outlook may be further complicated by economic recoveries, ongoing supportive policies, and the evolving nature of the shock. ${ }^{8}$ To help establish the significance of global food prices in domestic inflation, a simple model of inflation is specified and estimated using panel data techniques. The transmission of monetary policy through policy interest rates is also examined in this framework. Inflation outcomes under alternative scenarios for global wheat prices are then considered for each of the CA-4 using simple AR models.

\footnotetext{
${ }^{6}$ See tables in Appendix II for a comparison of the administrative measures during each shock episode.

${ }^{7}$ Indeed, the food price shock of 2007 was initially reflected in a wider range of products - such as rice, meats, breads, and cooking oils - whereas the 2010 shock was initially reflected in wheat and flour-with disruptions to wheat crops in several major producing regions (Russia, Kazakhstan, and Ukraine) - before spreading to other commodities.

${ }^{8}$ Global energy prices have risen sharply in recent months, reflecting adverse weather conditions in Australia and the United States, political unrest in North Africa and the Middle East, and increased demand from fast growing emerging economies.
} 
The model is specified to capture inflation inertia, the monetary policy stance, aggregate demand effects, and external inflationary pressures. ${ }^{9}$ Monthly data for December 2003 to October 2010 to capture the two recent episodes of global commodity price surges. The explanatory variables include lagged inflation, policy interest rates, excess money, nominal exchange rates, and global food and oil price inflation. ${ }^{10}$ The model uses lagged values of the explanatory variables to avoid potential endogeneity. Specifically,

$$
\pi_{i t}=\alpha \pi_{i t-1}+\beta x_{i t}+\gamma w_{t}+\varphi_{i}+\mu_{i t}
$$

where $\pi_{i t}$ is annual inflation, $i$ and $t$ represent the cross-section and time dimensions, $x_{i t}$ is the vector capturing predetermined or possibly endogenous variables reflecting monetary policy and aggregate demand, and the vector $w_{t}$ captures exogenous factors, including global food and oil prices. Time invariant fixed effects are captured by $\varphi_{i}$, while $\mu_{i t}$ is the country specific error term, assumed iid. Table 2 presents the results of the preferred specification, where alternative fixed effects estimation methods, including pooled OLS and GMM, were employed to ensure robustness of the results. ${ }^{11}$

The impact of the explanatory variables on inflation is as expected. All coefficients have the appropriate signs and are significant at conventional levels, while the overall lag structure is consistent with findings in the literature. ${ }^{12}$ In particular, monetary policy tightening lowers inflation with a lag of about seven months, while an increase in aggregate demand pressures, nominal exchange rate depreciation, and higher global food prices have a more immediate and positive impact on inflation. Global oil prices were not found to be significant in the model, likely reflecting the abundant oil supply in Kazakhstan and the regulation of energy prices in Kazakhstan and Uzbekistan.

\footnotetext{
${ }^{9}$ See Habermeier et al (2009) for a similar specification.

${ }^{10}$ Excess money growth is defined as the deviation of seasonally adjusted broad money (here taken M2) from its linear trend obtained with an HP filter. This specification is used to account for the uncertainties surrounding the stability of money demand functions in these economies (see Mohanty and Klau (2001)). The model was also estimated with credit growth in place of excess money, and similar results were obtained.

${ }^{11}$ It is widely known that pooled OLS coefficient estimates may be biased in the presence of a lagged dependent variable, and this is corrected for by using GMM.

${ }^{12}$ For example, see Habermeier et al (2009) and Mohanty and Klau (2001).
} 
Table 2. Estimating drivers of inflation in the CA-4

\begin{tabular}{|c|c|c|c|}
\hline & $\begin{array}{l}\text { [1] } \\
\text { Pooled } \\
\text { OLS }\end{array}$ & $\begin{array}{l}\text { [2] } \\
\text { Pooled } \\
\text { OLS } \\
\text { Within } \\
\text { Groups }\end{array}$ & $\begin{array}{l}\text { [3] } \\
\text { IV } \\
\text { GMM } \\
\text { Within } \\
\text { Groups } \\
\end{array}$ \\
\hline L1 Inflation & $\begin{array}{l}0.917 \\
{[0.019]^{*}}\end{array}$ & $\begin{array}{l}0.931 \\
{[0.031]^{*}}\end{array}$ & $\begin{array}{l}0.890 \\
{[0.033]^{*}}\end{array}$ \\
\hline L1 Excess Money & $\begin{array}{l}0.039 \\
{[0.015]^{\star *}}\end{array}$ & $\begin{array}{l}0.041 \\
{[0.014]^{* *}}\end{array}$ & $\begin{array}{l}0.072 \\
{[0.021]^{*}}\end{array}$ \\
\hline L1 Global Food inflation & $\begin{array}{l}0.028 \\
{[0.006]^{*}}\end{array}$ & $\begin{array}{l}0.024 \\
{[0.006]^{*}}\end{array}$ & $\begin{array}{l}0.026 \\
{[0.09]^{\star *}}\end{array}$ \\
\hline L1D Exchange rate & & & $\begin{array}{l}0.346 \\
{[0.213]^{\star * *}}\end{array}$ \\
\hline L2D Exchange rate & $\begin{array}{l}0.119 \\
{[0.048]^{\star *}}\end{array}$ & $\begin{array}{l}0.116 \\
{[0.063]^{\star * *}}\end{array}$ & \\
\hline L7 Policy Rate & $\begin{array}{l}-0.036 \\
{[0.022]^{\star * *}}\end{array}$ & $\begin{array}{l}-0.128 \\
{[0.041]^{\star}}\end{array}$ & $\begin{array}{l}-0.152 \\
{[0.048]^{\star *}}\end{array}$ \\
\hline Constant & $\begin{array}{l}0.010 \\
{[0.002]^{*}}\end{array}$ & $\begin{array}{l}0.018 \\
{[0.005]^{*}}\end{array}$ & $\begin{array}{l}0.023 \\
{[0.006]^{*}}\end{array}$ \\
\hline Observations & 277 & 277 & 273 \\
\hline R-Squared & 0.931 & 0.933 & 0.871 \\
\hline
\end{tabular}

The results suggest that the role of global food prices in contributing to domestic inflation is considerable in the CA-4. ${ }^{13}$ The large and rapid pass-through of global food prices is not unexpected given the hefty share that food takes in overall CPI baskets, the magnitude of the recent global shocks, and the ineffectiveness of administrative measures over sustained periods. In this context, the near-term exchange rate impact is also quite large, but the significance levels of these estimates remain below that of the other explanatory variables, likely reflecting the managed nature of these currencies. ${ }^{14}$ Finally, the transmission of monetary policy is rather limited, only impacting in the model with delayed notable lag.

\footnotetext{
${ }^{13}$ This finding is in line with that of Habermeier et al. (2009), but the relatively larger impact of global food inflation found here is reflective of the importance of food weight in the CPI basket than found in the previously mentioned study, which includes a set of middle income countries that carry lower food weights. See Chapter I of IMF (2011) for an analysis of the importance of global food price shocks in determining inflation in Kazakhstan.

${ }^{14}$ For example, see Mohanty and Klau (2001) where the exchange rate was found to be significant in only a subset of their sample, while Habermeier et al (2009) were unable to find the exchange rate significant in using a similar model to that presented here.
} 


\section{Box 3. Simulating a Sustained Global Wheat Price Shock}

Inflation outcomes under alternative scenarios for the global price of wheat are considered here. The focus on wheat prices reflects the importance of bread and cereals products in these countries' consumption baskets and keeps the analysis simple, avoiding the need to account for factors such as knock-on effect to other food prices, inflation expectations, or consequent administrative responses. In addition, the models do not attempt to account for any additional policy responses, providing inflation outcomes under a "quasiaccommodative" policy stance. Therefore, the potential impact on overall prices is likely to be even stronger than observed here.

Figure B3.1.Global wheat price scenarios and CA-4 bread inflation

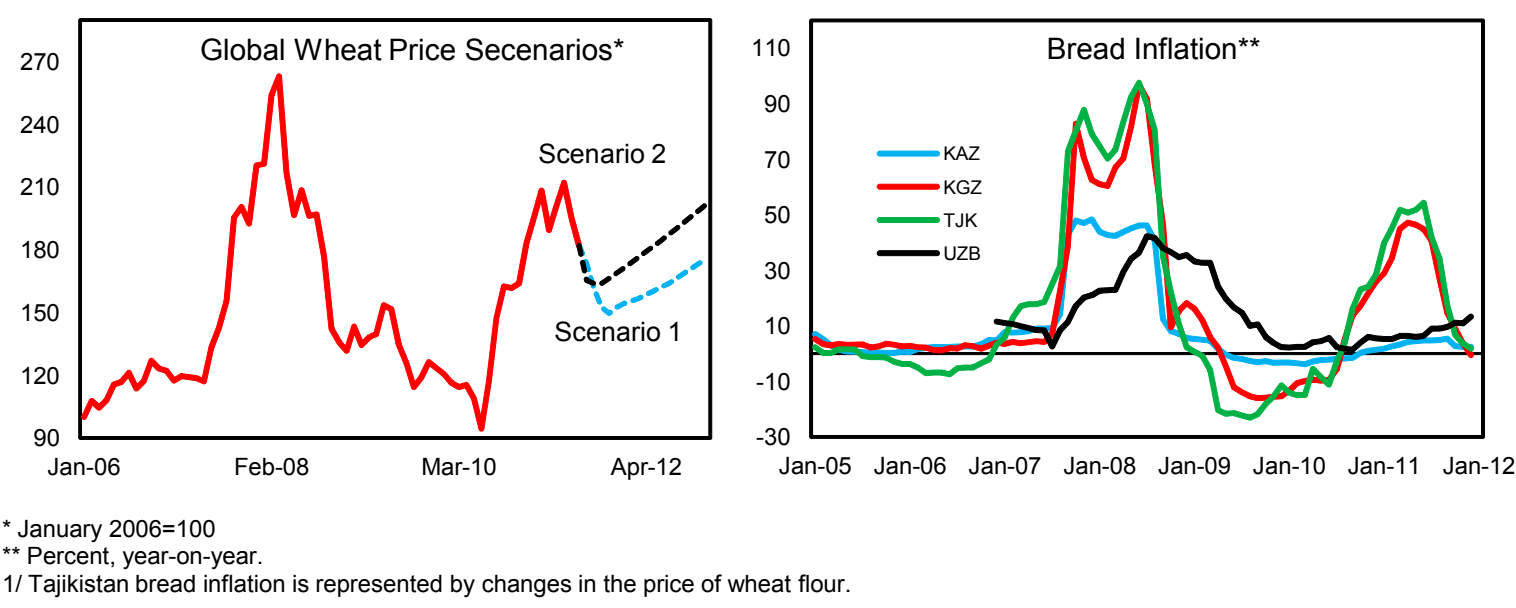

Using WEO wheat price forecasts, the results show that the potential inflation outcomes under a sustained episode of a wheat price shock are substantial for the Kyrgyz Republic and Tajikistan.

- $\quad$ The estimated pass-through of global wheat prices to domestic inflation was generated using a simple autoregressive model for each country, with monthly bread inflation depending on lags of itself and alternative forecasts for global wheat prices. ${ }^{15,16}$ The estimates for bread inflation were then scaled by their respective CPI weights and added to a naïve forecast for headline inflation to simulate the impact from alternative wheat price assumptions. ${ }^{17}$

Two cases were considered for the period July 2011 to December 2012. Scenario 1 is based on the global wheat price forecast in the June 2011 WEO Update. Scenario 2 is a more pessimistic case, and is based on the assumption that the global wheat price shock that started in 2010 will be as sustained as was observed in the 2007-08 shock. $^{18}$

\footnotetext{
${ }^{15}$ Monthly data from January 2004 to June 2011 are used in the model. See Appendix III for estimation results.

${ }^{16}$ Additional exercises were conducted for each country using global food inflation and domestic headline inflation, but the relationships were not significant in this simple autoregressive framework.

${ }^{17}$ The naïve models of headline inflation are linear trend models.

${ }^{18}$ The cumulative wheat price increase for the shock that started in 2010 is assumed to be at the same level as that of the 2007 shock.
} 
- $\quad$ Table B3.1 provides the results, where the naïve model is presented as a relative benchmark. As expected, in both scenarios headline inflation rises considerably in 2012 relative to the naïve model. The inflation outcomes under both scenarios are more pronounced in the Kyrgyz Republic and Tajikistan as these countries are net importers of wheat, while administrative measures to control bread prices have been mostly absent.

Table B3.1. Alternative inflation forecasts for 2012

(In percent year-on-year, e.o.p.)

\begin{tabular}{lrrrr}
\hline & KAZ & KGZ & TJK & UZB \\
\cline { 2 - 5 } Trend & 7.4 & 9.0 & 8.1 & 8.7 \\
Scenario 1 & 8.2 & 11.9 & 11.1 & 10.6 \\
Scenario 2 & 8.3 & 12.7 & 12.6 & 10.8 \\
\hline
\end{tabular}

\section{Global Food Shocks and CA-4 Policy Measures}

CA-4 policymakers have relied mainly on administrative measures to soften the pass-through of international food price inflation. ${ }^{19}$ These have primarily included food and commodity export controls, moral suasion, price controls, and the replenishment and deployment of grain and key staple reserves (see Appendix II Tables A2.1 and A2.2). In addition to these measures, some countries have raised pensions and wages to mitigate the effects of higher food prices on vulnerable groups. Nevertheless, as the findings above suggest, the CA-4 are vulnerable to a sustained global food price shock.

A combination of structural and institutional features in the CA-4 has conditioned the policy responses to the global inflationary pressures. The traditional heavy reliance on administrative measures in the CA-4 reflects the legacy of heavy government interference. ${ }^{20}$ It also reflects a lack of domestic competition and productive capacity across industries. In addition, other policy objectives - such as maintaining external competitiveness and achieving developmental benchmarks - contribute to procyclical fiscal stances and growth-centric monetary policies, common in these countries. ${ }^{21}$ Finally, institutional shortcomings limit the efficient administration of targeted social assistance, often resulting in blanket wage and pension increases - as recently observed in Kazakhstan and the Kyrgyz Republic.

The results presented above point to a potentially more significant role for monetary policy in controlling broad-based inflationary pressures. However, given the transmission

${ }^{19}$ Administrative measures are not widely employed in Tajikistan and the Kyrgyz Republic since they lack sufficient resources to effectively implement such measures.

${ }^{20}$ See IMF 2010 (Annex 3.1) for an examination of the transmission of monetary policy in the Caucasus and Central Asia countries.

${ }^{21}$ See Abdih et al (2010) for a discussion and evidence on procyclical fiscal stances in emerging and developing economies. 
lags observed in Table 2, monetary frameworks must become credible, proactive, and forward-looking to be more effective. This includes a greater degree of central bank independence than is currently observed in the CA-4 (Box 3). In general, legal independence - supported in many cases by IMF technical assistance-is relatively well established in these countries, but could be strengthened to ensure that price stability is the overriding policy objective. This would provide a strong basis to promote an orderly transition to greater de facto independence over monetary policy.

\section{Box 4. Central Bank Independence in the CA-4}

Central bank independence is positively related with successful inflation control. Using measures developed by Cukierman (1992) and Crowe and Meade (2008), independence and transparency of the CA-4 central banks were assessed on a de jure basis (based on central bank laws). ${ }^{22}$ Central bank de jure independence is defined as a function of four sets of variables: (i) appointment, dismissal, and term of office of the governor; (ii) policy formulation responsibility; (iii) main objectives; and (iv) limitations on lending to the government. Transparency measures are derived from a questionnaire describing central bank activities (Appendix IV).

Table B4.1. Measures of central bank independence in the CA-4 ${ }^{23}$

\begin{tabular}{lcc}
\hline & Legal Independence & Transparency \\
\hline Kazakhstan & 0.60 & 0.50 \\
Kyrgyz Republic & 0.89 & 0.40 \\
Tajikistan* & 0.67 & 0.30 \\
Uzbekistan & 0.49 & 0.20 \\
\hline Average & $\mathbf{0 . 6 6}$ & $\mathbf{0 . 3 5}$ \\
\hline
\end{tabular}

Note: Final Scores are normalized to be between 0 and 1, with 0 being very poor and 1 being very strong.

* Tajikistan's scores are based on the central bank law as of November 2010.

CA-4 central banks score relatively well with regard to legal independence. The respective laws could be strengthened by clearly formulating the central banks' key policy objectives, strengthening governance structures, limiting interference from executive and legislative branches of government, introducing public reporting requirements, and imposing legal limits on lending to the government.

On transparency, all of the central banks perform poorly. While analytical and statistical information is published, little is disclosed regarding the policy-making process.

\section{Policy Considerations And Conclusions}

This paper analyzes the role of global food prices in the determination of inflation in the CA-4. The findings suggest that global food prices have a strong and significant short-run impact on headline inflation in these economies, adding to the effects from other more traditional factors - inflation inertia, money creation, and currency depreciation. In addition,

\footnotetext{
${ }^{22}$ The methodology focuses on the assessment of central bank independence mainly on monetary policy issues.

${ }^{23}$ Based on end-2003 data Arnone et al. (2007) find the similar rankings for these countries in terms of de jure central bank independence. European Central Bank had the highest score of 1.00.
} 
simple simulations under a sustained global wheat price shock underscore the risks to more broad-based inflation in the CA-4, particularly for the net food importing countries.

CA-4 policymakers have traditionally employed administrative measures to combat the inflationary pressures arising from higher global food and commodity prices. This largely reflects a combination of structural and institutional features, the hitherto limited duration of global shocks, and the need to support growth and financial sector prospects. Moreover, as discussed above, institutional frameworks for monetary policy are generally weak in the CA-4, while monetary transmission appears limited at short horizons.

Nevertheless, while the use of administrative measures may provide near-term relief, these should be exclusive, transparent, and time-bound. Despite these limitations, however, there are additional short-term measures that the authorities could consider to help guard against the emergence of second-round price effects. Such actions are particularly relevant when the uncertainty regarding the outlook for global commodity prices increases. These include:

- Improving the communication of monetary policy. Central banks should clearly communicate their analysis of the determinants and expected causes of inflation, as well as their inflation objectives. Central banks should continue focusing on stabilizing core inflation, but should use headline inflation as a key indicator of future prices pressures in order to ensure a timely monetary policy response.

- Actively utilizing existing monetary instruments. Policy rates should be adjusted to ensure that real interest rates are kept positive. Growth rates of monetary aggregates should be closely monitored, and sterilization efforts should be enhanced if necessary, while implicit exchange rate targets may also need to be reconsidered.

Although the role of fiscal policy was not specifically addressed here, it is clear that a prudent fiscal stance is needed to avert more broad-based price pressures. In this regard, to the extent possible, fiscal policy should support price stability and guard against pro-cyclicality, while balancing the need to maintain essential support to vulnerable sectors of society. In addition, existing social safety nets should be employed to protect the most vulnerable groups from the pass-through of higher commodity prices. Measures, such as blanket wage and pension increases, should be avoided as they may have distortionary impacts and are hard to reverse.

Looking further ahead, efficient monetary policy transmission, adequate social safety nets, and structural reforms will mitigate the need for administrative measures in the CA-4. In particular, reforms should be pursued to:

- Improve monetary policy efficiency. Central bank independence should be strengthened and protected in legal frameworks, with price stability clearly defined as the main objective. This should be accompanied by measures to enhance the monetary policy toolkit, including by promoting the development of domestic 
financial markets, while competition in the banking sector should be encouraged to ensure that interest rates reflect market conditions.

- Develop adequate social safety nets. Existing institutional mechanisms should be strengthened, or developed where they are absent, to identify and provide timely, well targeted and efficient assistance to the most vulnerable groups, particularly as administrative measures are phased out.

- Enhance supply response and economic resilience. Structural measures to improve competitiveness, labor market flexibility, and productivity should be pursued, particularly in agriculture. 


\section{References}

Abdih, Y., Lopez-Murphy, P., Roitman, A., and Sahay, R. (2010). The Cyclicality of Fiscal Policy in the Middle East and Central Asia. IMF Working Paper No. 10/68. International Monetary Fund, Washington DC.

Arnone, M., Laurens, B.J., Segalotto, J., and Sommer, M. (2007). Central Bank Autonomy: Lessons from Global Trends. IMF Working Paper No. 07/88. International Monetary Fund, Washington DC.

Crowe, C.W., and Meade, E.E. (2008). Central Bank Independence and Transparency:

Evolution and Effectiveness. IMF Working Paper No. 08/119. International Monetary Fund, Washington DC.

Cukierman, A. (1992). Central Bank Strategy, Credibility, and Independence: Theory and Evidence. Cambridge, MA, EE.UU.: MIT Press.

Habermeier, K., Otker-Robe, I., Jacome, L., Guistiniani, A., Ishi, K., Vavra, D., Kisinbay, T., Vazquez, F. (2009). Inflation Pressures and Monetary Policy Options in Emerging and Developing Countries: A Cross Regional Perspective. IMF Working Paper No. 09/1. International Monetary Fund, Washington DC.

IMF (2010). Regional Economic Outlook, Middle East and Central Asia. International Monetary Fund, Washington DC.

IMF (2011). Republic of Kazakhstan: Selected Issues. Country Report 11/151. International Monetary Fund, Washington DC.

Khan, Mohsin S., and Abdelhak Senhadji, 2001, "Threshold Effects in the Relationship Between Inflation and Growth," IMF Working Paper No. 00/110; IMF Staff Papers, Vo. 48, No. 1, pp. 1-21. International Monetary Fund, Washington DC.

Mohanty, M.S., and Klau, M. (2001). What Determines Inflation in Emerging Market Economies? In "Modelling Aspects of the Inflation Process and the Monetary Transmission in Emerging Market Economies," BIS Paper No. 8, Bank For International Settlements. 


\section{Appendix I}

Table A1.1. Major food staples in the CA-4-Demand and supply

\begin{tabular}{|c|c|c|c|c|c|c|c|c|}
\hline & \multicolumn{2}{|c|}{ Bread } & \multicolumn{2}{|c|}{ Carrots } & \multicolumn{2}{|c|}{ Flour } & \multicolumn{2}{|c|}{ Onion } \\
\hline & Demand & Supply & Demand & Supply & Demand & Supply & Demand & Supply \\
\hline UZB & $\mathrm{D}$ & D & D & D & $\mathrm{D} / \mathrm{F}$ & $\mathrm{D} / \mathrm{F}$ & $\mathrm{D}$ & D \\
\hline TJK & $\mathrm{D}$ & D & D & D & $\mathrm{D}$ & $\mathrm{D}(65 \%) / \mathrm{F}(35 \%)$ & D & $\mathrm{D}$ \\
\hline KGZ & $\mathrm{D}$ & D & $\mathrm{D}(89 \%) / \mathrm{F}(11 \%)$ & D & D & $\mathrm{D}(88 \%) / \mathrm{F}(12 \%)$ & $\mathrm{D}(93.6 \%) / \mathrm{F}(6.4 \%)$ & $\mathrm{D}(98.5 \%) / \mathrm{F}(1.5 \%)$ \\
\hline \multicolumn{9}{|c|}{ - } \\
\hline & \multicolumn{2}{|c|}{ Potatoes } & \multicolumn{2}{|c|}{ Rice } & \multicolumn{2}{|c|}{ Meat } & \multicolumn{2}{|c|}{ Milk } \\
\hline & Demand & Supply & Demand & Supply & Demand & Supply & Demand & Supply \\
\hline UZB & $\mathrm{D}$ & D & D & D & D & D & ( & \\
\hline TJK & D & $\mathrm{D} / \mathrm{F}$ & D & $\mathrm{D} / \mathrm{F}$ & D & D & & \\
\hline KGZ & $\mathrm{D}(63.3 \%) / \mathrm{F}(36.7 \%)$ & $\mathrm{D}$ & $\mathrm{D}(92.6 \%) / \mathrm{F}(7.4 \%)$ & $\mathrm{F}(88.5 \%) / \mathrm{D}(11.5 \%)$ & $\mathrm{D}(79.9 \%) / \mathrm{F}(20.1 \%)$ & $\mathrm{D}(74.4 \%) / \mathrm{F}(25.6 \%)$ & $\mathrm{D}(92 \%) / \mathrm{F}(8 \%)$ & $\mathrm{D}(97.2 \%) / \mathrm{F}(2.8 \%)$ \\
\hline \multicolumn{9}{|l|}{ KAZ } \\
\hline & \multicolumn{2}{|c|}{ Eggs } & \multicolumn{2}{|c|}{ Vegetable oil } & \multicolumn{2}{|c|}{ Sugar } & & \\
\hline & Demand & Supply & Demand & Supply & Demand & Supply & & \\
\hline UZB & & & $\mathrm{D} / \mathrm{F}$ & $\mathrm{D} / \mathrm{F}$ & $\mathrm{D} / \mathrm{F}$ & $\mathrm{D} / \mathrm{F}$ & & \\
\hline TJK & & & D & $\mathrm{D} / \mathrm{F}$ & D & $\mathrm{F}$ & & \\
\hline KGZ & $\mathrm{D}$ & $\mathrm{D}(89.6 \%) / \mathrm{F}(10.4 \%)$ & D & $\mathrm{F}(62.3 \%) / \mathrm{D}(37.7 \%)$ & & & & \\
\hline KAZ & & & & & & & & \\
\hline
\end{tabular}

Table A1.2. Major food staples in the CA-4-Production and exports

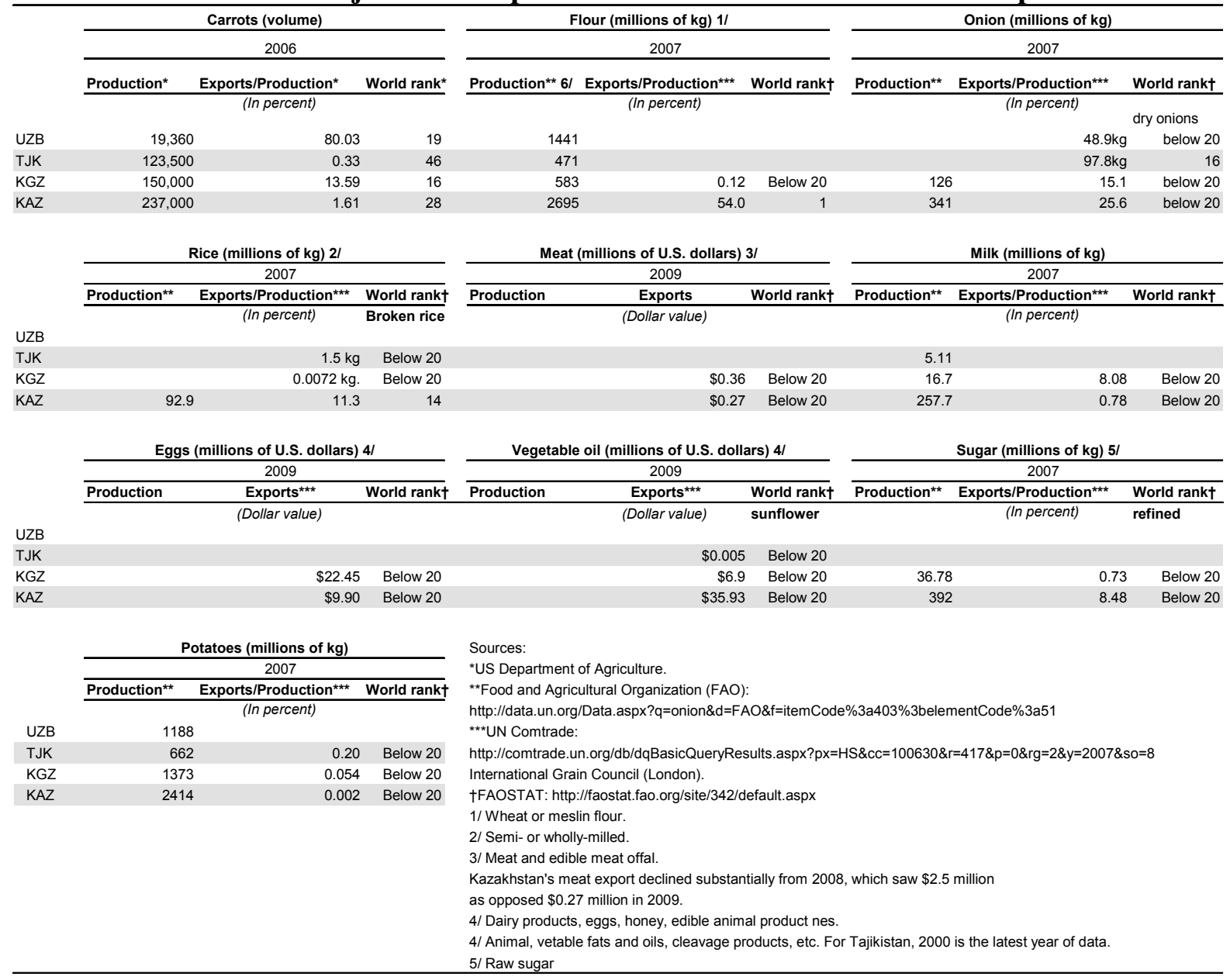


Figure A1.1: CA-4 and world food price indices, December $1995=100$
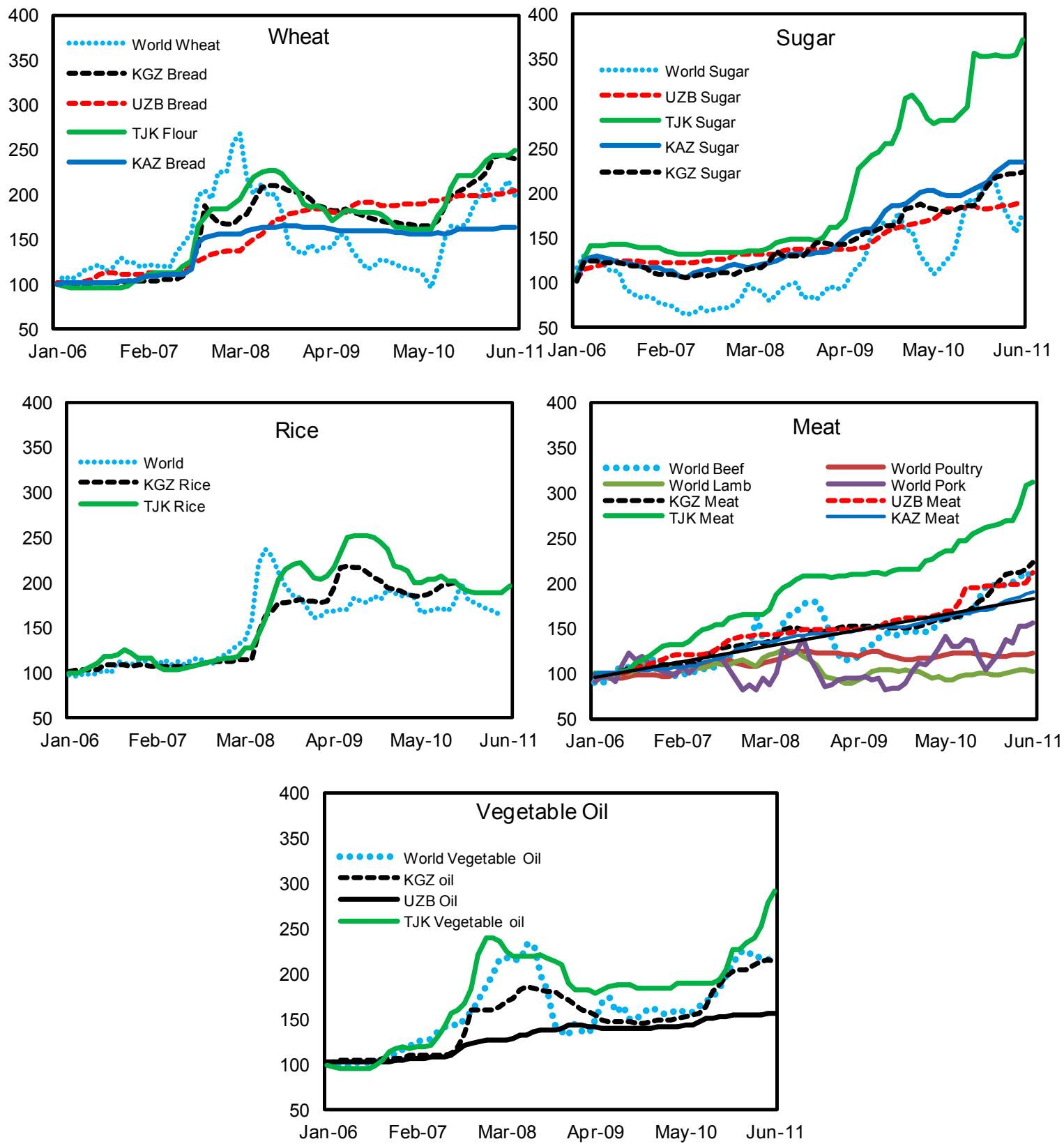

Sources: Country authorities' data, staff estimates, Food and Agricultural Organization of the United Nations (FAO), IFTS, and WEO. 


\section{Appendix II}

Table A2.1. Public policy responses to food price increases 2007-08

\begin{tabular}{|c|c|c|c|c|c|}
\hline Country & $\begin{array}{l}\text { Export Restrictions/ } \\
\text { Import } \\
\text { Liberalization }\end{array}$ & Domestic Price Controls & $\begin{array}{l}\text { State Procurement \& } \\
\text { Distribution }\end{array}$ & Wage & Pension \\
\hline Kazakhstan & $\begin{array}{l}\text { In Q3 } 2007 \text { adopted } \\
\text { ban (lifted in October } \\
\text { 2008) on export of } \\
\text { flour, sunflower seeds, } \\
\text { and vegetable oil. } \\
\text { Import tariffs on } \\
\text { vegetable oil } \\
\text { temporarily set at nil } \\
\text { and lowered import } \\
\text { tariffs on sugar, rice, } \\
\text { sausages, cheese, milk, } \\
\text { butter, fish, fruits, and } \\
\text { vegetables. }\end{array}$ & $\begin{array}{l}\text { State trade inspection } \\
\text { monitored prices for } \\
\text { basic foodstuffs to } \\
\text { prevent price gauging. }\end{array}$ & $\begin{array}{l}\text { State grain reserve not } \\
\text { used; domestic grain } \\
\text { purchased for the new } \\
\text { regional grain } \\
\text { stabilization funds. }\end{array}$ & & \\
\hline Kyrgyzstan & $\begin{array}{l}\text { South regions banned } \\
\text { the export of flour and } \\
\text { grain, but the ban } \\
\text { difficult to enforce. } \\
\text { VAT threshold for } \\
\text { flour and bread } \\
\text { producers and } \\
\text { importers increased to } \\
\text { lower incentives for } \\
\text { price increase by SME } \\
\text { producers. }\end{array}$ & $\begin{array}{l}\text { Profit margins of large } \\
\text { flour producers } \\
\text { monitored by state } \\
\text { regulatory institutions. }\end{array}$ & $\begin{array}{l}\text { Sales by State Grain } \\
\text { Reserve fund. } \\
\text { Subsidized bread prices } \\
\text { for pensioners } \\
\text { (temporary). }\end{array}$ & $\begin{array}{l}\text { Public } \\
\text { sector } \\
\text { wages } \\
\text { increases } \\
\text { motivated } \\
\text { partly by } \\
\text { food } \\
\text { price } \\
\text { shock. }\end{array}$ & $\begin{array}{l}\text { Pensions } \\
\text { increases } \\
\text { motivated } \\
\text { partly by } \\
\text { food price } \\
\text { shock. }\end{array}$ \\
\hline Tajikistan & & & $\begin{array}{l}\text { No change. State } \\
\text { procurement only for } \\
\text { health and social } \\
\text { protection institutions. }\end{array}$ & $\begin{array}{l}\text { No } \\
\text { change or } \\
\text { food } \\
\text { subsidy. }\end{array}$ & \\
\hline Uzbekistan & $\begin{array}{l}\text { Self-sufficient in } \\
\text { foodstuffs supply. } \\
\text { No grain, flour or rice } \\
\text { exports permitted } \\
\text { (formal restriction) } \\
\text { since } 1994 \text {. }\end{array}$ & $\begin{array}{l}\text { No specific policy } \\
\text { response. Prices on } \\
\text { domestically produced } \\
\text { grain, flour, and "social" } \\
\text { bread controlled by the } \\
\text { state. } \\
\text { Prices of cooking oil } \\
\text { controlled in } 2007-08 \text {. }\end{array}$ & $\begin{array}{l}\text { No specific policy } \\
\text { response. Fifty percent } \\
\text { of grain procured by the } \\
\text { state. The rest sold by } \\
\text { farmers through local } \\
\text { markets. State owned } \\
\text { flour mills produce } \\
\text { most of flour. Farmers } \\
\text { use privately owned } \\
\text { 'mini-mills' for wheat } \\
\text { not-procured by the } \\
\text { state. } \\
\text { Increased acreage for } \\
\text { planting wheat, fruits, } \\
\text { vegetables, forage } \\
\text { fodder. }\end{array}$ & $\begin{array}{l}\text { Grain } \\
\text { reserve } \\
\text { created } \\
\text { following } \\
\text { the price } \\
\text { surge. }\end{array}$ & \\
\hline
\end{tabular}


Table A2.2. Public policy responses to food price increases 2010-11

\begin{tabular}{|c|c|c|c|c|c|}
\hline Country & $\begin{array}{l}\text { Export Restrictions/ } \\
\text { Import Liberalization }\end{array}$ & Domestic Price Controls & $\begin{array}{l}\text { State Procurement } \\
\text { \& Distribution }\end{array}$ & Wage & Pension \\
\hline \multirow[t]{3}{*}{ Kazakhstan } & $\begin{array}{l}\text { Export duties levied on } \\
\text { crude oil and } \\
\text { petrochemicals } \\
\text { products in November } \\
2010 \text {, and increased for } \\
\text { petrochemicals } \\
\text { products in July } 2011 .\end{array}$ & $\begin{array}{l}\text { State Agricultural company } \\
\text { to assure stable grain prices; } \\
\text { the company signed } \\
\text { memorandums with grain } \\
\text { producers and processors to } \\
\text { control bread prices until } \\
\text { September } 2011 \text {. }\end{array}$ & $\begin{array}{l}\text { State grain reserve } \\
\text { augmented to eight } \\
\text { million tons with a } \\
\text { purchase of two } \\
\text { million tons of } \\
\text { domestic grain in } \\
2010 \text {. }\end{array}$ & $\begin{array}{l}\text { Pre- } \\
\text { planned } \\
\text { wage } \\
\text { increase in } \\
\text { both } 2010 \\
\text { and } 2011 \text {. }\end{array}$ & $\begin{array}{l}\text { Pre- } \\
\text { planned } \\
\text { pension } \\
\text { increase in } \\
\text { both } 2010 \\
\text { and } 2011 .\end{array}$ \\
\hline & & $\begin{array}{l}\text { New legislation is under } \\
\text { consideration, which would } \\
\text { give the government the } \\
\text { power to set regional price } \\
\text { rise limits on staple food } \\
\text { items. Further price } \\
\text { subsidies for food producers } \\
\text { are being considered. }\end{array}$ & $\begin{array}{l}\text { State grain reserve } \\
\text { sold one million } \\
\text { tons of grain to } \\
\text { producers in August } \\
2011 \text { at below } \\
\text { market values to } \\
\text { stabilize the } \\
\text { domestic market. }\end{array}$ & & \\
\hline & & $\begin{array}{l}\text { Wholesale and retail price } \\
\text { limits on gasoline products } \\
\text { set by the Ministry of Oil } \\
\text { and Gas in July } 2011 \text {. }\end{array}$ & & & \\
\hline \multirow[t]{2}{*}{ Kyrgyzstan } & $\begin{array}{l}\text { Import duties on wheat } \\
\text { lowered by two-thirds. } \\
\text { Agreement reached } \\
\text { with Kazakhstan to } \\
\text { import } 40 \text { percent of } \\
\text { imported wheat at a } \\
\text { fixed price. }\end{array}$ & $\begin{array}{l}\text { Anti-monopoly agency } \\
\text { pressures grain producers to } \\
\text { reverse recent price } \\
\text { increases. }\end{array}$ & & & \\
\hline & $\begin{array}{l}\text { VAT exemption } \\
\text { threshold for producers } \\
\text { and importers of flour } \\
\text { and bread raised to } \\
\text { lower tax pass through } \\
\text { to market prices. }\end{array}$ & & & & \\
\hline Tajikistan & & $\begin{array}{l}\text { Wheat VAT reduced by } \\
50 \text { percent to ease prices } \\
\text { pressures. } \\
\text { Price controls on foodstuffs } \\
\text { in Dushanbe during } \\
\text { August-September } \\
\text { (Ramadan). }\end{array}$ & $\begin{array}{l}\text { The resources of } \\
\text { State Reserve } \\
\text { Agency increased, } \\
\text { but no intervention } \\
\text { carried out or } \\
\text { planned. }\end{array}$ & & \\
\hline Uzbekistan & $\begin{array}{l}\text { Indicative production } \\
\text { and export limits. }\end{array}$ & $\begin{array}{l}\text { No specific policy } \\
\text { response-administered } \\
\text { bread prices adjusted at rates } \\
\text { above planned rates. }\end{array}$ & & & \\
\hline
\end{tabular}




\section{Appendix III}

Table A3.1. Estimating global wheat impacts on bread price inflation

\begin{tabular}{|c|c|c|c|c|}
\hline & Kazakhstan & Kyrgyz Republic & Tajikistan & Uzbekistan \\
\hline \multicolumn{5}{|l|}{ Bread price } \\
\hline \multirow[t]{2}{*}{ L1 } & 0.6 & 0.277 & 0.286 & 0.368 \\
\hline & {$[0.083]^{* *}$} & {$[0.096]^{\star *}$} & {$[0.097]^{\star *}$} & {$[0114]^{* *}$} \\
\hline \multirow{2}{*}{ WEO wheat price } & & & 0.238 & \\
\hline & & & {$[0.052]^{* *}$} & \\
\hline \multirow[t]{2}{*}{ L1 } & & 0.205 & & \\
\hline & & {$[0.055]^{\star *}$} & & \\
\hline \multirow[t]{2}{*}{ L2 } & & & 0.151 & 0.050 \\
\hline & & & {$[0.055]^{*}$} & {$[0.023]^{*}$} \\
\hline \multirow[t]{2}{*}{ L3 } & 0.041 & & & \\
\hline & {$[0.018]^{*}$} & & & \\
\hline \multirow[t]{2}{*}{ Constant } & 0.267 & 0.587 & 0.375 & 0.623 \\
\hline & [0.151] & {$[0.434]$} & [0.448] & {$[0.239]^{\star *}$} \\
\hline Observations & 87 & 89 & 77 & 65 \\
\hline R-squared & 0.46 & 0.26 & 0.40 & 0.20 \\
\hline F-statistics & 35.65 & 14.87 & 15.95 & 7.64 \\
\hline Durbin Watson & 1.76 & 2.00 & 2.13 & 2.11 \\
\hline
\end{tabular}




\section{Appendix IV}

\section{Table A4.1. Questionnaire on transparency of central bank operations}

1 Political

1.1 Is there a statutory objective?

Single objective of price stability or price stability objective does not conflict with other objectives

Price stability objective potentially conflicts with other objectives

Objectives do not include price stability or no objective

1.2 Is there an explicit numerical target for prices or inflation?

Yes

No

2 Economic

2.1 Does the central bank publish surveys (conducted by itself or others) that could be used to estimate inflation expectations?

Yes

No

2.2 Does the central bank publish any forward-looking analyses such as forecasts?

Words AND numbers/figures

Words OR numbers/figures

Neither

3 Procedural

3.1 Does central bank publish minutes of policy meetings?

Yes

No

3.2 Does central bank publish voting patterns of monetary policy committee?

Yes

No

4 Policy

4.1 Does central bank publish explanations on day policy changed?

Yes

No

4.2 Does central bank publish explanations on day policy does not change?

Yes

No

5 Operational

5.1 Does central bank publish discussion of risks to outlook or forecast?

Words AND numbers/figures

Words OR numbers/figures

Neither

5.2 Does central bank publish discussion of shocks or forecast errors after the fact?

Yes

No

Source: Crowe and Meade (2008). 